\title{
Settlement and clanship of Wolaitta in Omo River Valley of Ethiopia
}

\author{
Abesha Shirko Lambebo, Ratnakar Mohapatra
}

\begin{abstract}
The purpose of this article is to asses the settlement and clanship of Wolaitta in Omo River Valley of Ethiopia. The existing evidences do not indicate the settlement and clanship of Wolaitta in Omo River Valley of Ethiopia. The study was conducted through qualitative research method. Both primary and secondary sources were used. Based on the sources, the study proved that Dolla-Woyisha clan has been first born inhabitants of Wolaitta in Omo River Valley, and the study avoids confusion on the settlement and clanship of Wolaitta in Omo River Valley. Thus, early inhabitants known as Dolla-Woyisha clan has been assimilated with the immigrant clan of Tossa-Woyisha which led to the developments of settlement and clanship in Wolaitta. Finally, based on findings, the existence of early clan along with the domestication of crops such as uta (false banana), and Wolaitta-donuwa (Wolaitta-potato) and animals such as so-mehiya (cattle) proves the settlement and clanship of Wolaitta in Omo River Valley of Ethiopia.
\end{abstract}

Keywords : settlement, clanship, Wolaitta, Ethiopia.

\section{INTRODUCTION}

Settlement and complex social organization such as clanship are related with the Neolithic Revolution in river valley civilizations. During pre-Neolithic age (before 11,000 years ago), humans lived as hunters and gatherers. They also invented fire, and the stone was their dominant tool. For this reason, historians called it as a 'Stone Age.' The Neolithic period or late stone age was begun after 11, 000 years ago and followed with the domestication of plants and animals. The Neolithic period was also characterized by settlement, relatively advanced knowledge and complex

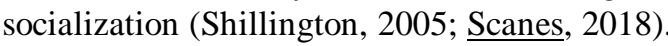

Thus, the beginning of settlements in fertile lands of River Valleys paved the way for the domestication of plants and animals. It also facilitated to various socio-cultural developments such practicing religion, shelter, and family formation. Human being started ploughing and produced crops, built their shelter and family establishment. The organization of family enabled to defend itself from others via war. The practice of religion needed to protect it from all calamities. They began religion and believed that the practitioners of the religious rituals as their agents with creator. They allowed leaders to guide and govern

Revised Manuscript Received on October 15, 2019.

* Correspondence Author

Abesha Shirko Lambebo, Assistant Professor, Department of History and Heritage Management, Wolaitta Sodo University, Ethiopia; PhD Research Scholar, Department of History, KISS, KIIT University, Bhubaneswar, India

Ratnakar Mohapatra, Assistant Professor, Department of History, KISS, KIIT University, Bhubaneswar, India. themselves. The leadership to control their area by war indicated the beginning for the formation of state. Other factors of socialization such as categorization of classes among the society such as religious agents, rulers, fighters, merchants, commoners, artisans and slaves were evolved (Spencer, 2010; Clark, 1962; Allen, 1997; Turchin, Whitehouse, Korotayev, Francois, Hoyer, Peregrine, and Currie, 2018)

Besides, various evidences about the beginning of sedentary way of life confirm that the settlements which were begun in River Valleys such as Nile, Tigris ans Euphrates, Yellow River and Yangtze, Indus and Ganges rivers were associated with various human achievements (Wescott, Feary, Brown, Marshall, Lilley, McKinnon, Verschuuren and Wild, 1970). The investigation of Brandt, Fisher, Hildebrand, Vogelsang, Ambrose, Lesur and Wang (2012) confirmed that Africa was a home for human origin. In similar way, Mokhtar (1981) confirms the Nile River valley is one of the indications of African settlements and its source is dominantly flow from Ethiopia.

According to linguists (Bender 1975, 1976, Fleming, 1976, 2006), Ethiopia is proto-Afroasiatic language family of four classifications. These are Nilo-Saharan, Cushetic, Semetic, and Omotic. Wolaitta is classified under the Omotic language family. The Omotic language is spoken to left and right side of Omo river, and Wolaitta is situated left bank of the river from its source of flow direction. The current zone of Wolaitta is situated between Hadiya and Kambatta, Aris and Sidama, Gamo-Gofa and Dawuro in the north, east, south and the west respectively. The site of Wolaitta exactly found between coordinate of $6^{\circ}$ North latitude, and $37^{\circ}$ East longitude. Wolaitta had various climate conditions such geziya (cold-highland), bariguwa (wet-midland), and gara (hot-lowland) (Lambebo, 2016; Jufare, 2008).

Wolaitta is also vital area in South Ethiopia in its culture and history in Omo River Valley (Cavanna, 2005; Spencer, 2010; Clark, 1962, Allen, 1997; Brandt, et'al., 2012, 2017). The culture and history of Amhara is taken as the only representation of Ethiopia. However, there are more than eighty ethnic group whose history is not recorded, and their culture is masked by the Amhara culture. Thus, their culture and history were seen from the view point of northern Ethiopia context, which degraded the development of South Ethiopian culture and literature at least in the $20^{\text {th }}$ century. The way of life of the entire ethnic groups in South Ethiopia was overlooked and most anthropological, cultural, archaeological and historical studies were focused to 
northern Ethiopia, and Southern part of the nation is given less attention because of lack of written language, bias and subjectivity. Besides, modern academic professionals of Ethiopia were not interested to cover the socio-cultural way of life in South Ethiopia including Wolaitta in Omo River Valley. For this reason, this article assess the settlement and clanship of Wolaitta in Omo River Valley of Ethiopia. The study bases on primary and secondary sources to indicate the early settlement and clanship of Wolaitta in Omo Valley of Ethiopia.

\section{METHODOLOGY}

The qualitative research method is used in this study. The central focus of this, ethnographic survey is Wolaitta zone (sub-province) which have 15 districts. Wolaitta is found in the South Ethiopia. The study used both written primary and oral sources. Since this study mainly focused on ethnographic approach, it used community elders who have basic knowledge about Wolaitta past. The key informants were selected purposefully and some were used in snowball technique. The informants were selected based on accumulated experiences and their consent. The written sources or documents were collected from Wolaitta Zone Culture, Tourism and Government Communication department, and various libraries and Culture centers in Wolaitta Soddo and Addis Ababa. The data collection method used include interview, focus group discussion, document-analyses and observations on how to assess the settlement and clanship in Wolaitta. After collecting the necessary data, qualitative interpretation was employed to explain the settlement and clanship of Wolaitta in Ethiopia.

\section{SETTLEMENT OF WOLAITTA}

The evidences indicates that Wolaitta in Omo River Valley of Ethiopia and caves in this area such as Wawu, Arujia, Moche-Borago, and others proved that the valley was the base of settlement of Wolaitta. Both natural and man-made caves indicate that people lived in Omo River Valley since long period. Omo River became the base to classify the language and people to be called Omotic. Thus, Wolaitta is an Omotic language family of Afro-Asiatic category, and Omotic Language was categorized in to Cushetic language until it as detached in 1960s (Bender, 1975, 1976; Fleming, 1976, 2006; Brown and Ogilivie, 2009; Amha, 2010). Wolaitta has the population of two million in its administrative unit and equivalent number outside it (Wolaitta Zone, 2017). Among the population of seventy-three million of the national population, Wolaitta share two percent (Central Statistical Authority, 2008).

The settlement in Ethiopia in general and Wolaitta in particular were dominantly linked with domestication of plants and animals. The domestication led to the foundation of family, living in small huts, leadership, religious activities, and other social developments (Balisky, 2009, p.23). Oral tradition and written records indicate that Wolaitta is one of the ancient uta (false-banana) and Wolaitta-donuwa (Wolaitta-potato) producing area since Neolithic period Ethiopia (Cerulli:1956:99; Olango, Tesfaye, Catellani and Pè, 2014; Doda, 2006). This is the confirmation that Wolaitta had a long experience of the domestication of uta as well as animals such as bora (ox), miziyo (cow) and kana (dog).

Uta and teff are linked with the domestication of plants in the South and North Ethiopia respectively. Through gradual process, various plants and animals were domesticated. Besides, Wolaitta was known for cattle herding known mehiya-hentta. The cattle herding (mehiya-hentta) tradition in Wolaitta include the accumulation of cattle to much numbers. The accumulation ceremony is inaugurated as dala and/or gimuwa, liqa, uma and shashoguwa, while cattle number reach to hundred, thousand, ten thousand and beyond ten thousand respectively (Hidoto, 2015). Livestock were used for food, transportation, plough and for personality cult (Ehret, 1979; Institute of Biodiversity Conservation, 2012, p. 23). Wolaitta oral tradition also confirms that Boroda-malla clan invented tama (fire) in the area. For this reason, the Boroda-mala clan witnessed by Wolaitta proverb tamaa kesiya boroda meaning a descent of Boroda-mala clan invented fire. This is one of the indications of the existence of evolution and settlement of Wolaitta at Omo River valley.

The archaeological and related sources confirm that Wolaitta was settled in the present territory of Omo River Valley since the time immemorial. Thus, Wolaitta settlement was affiliated with developments of caves such as Arujjia, Wawu, and Mochena-Borago. These caves were used to domesticate plants and animals. The Omo River Valley is rich in production of oldowan to the post-acheulean (Middle to late Stone Age) tools, and later developments of Neolithic Revolution, and this accelerated for various achievements (Brand et'al., 2012, 2017; Cavanna, 2005; Dunnavant, 2017), Amigoda (Zala Shasha) ). As similar to other river valleys settlements of the world, the climate change and subsequent development during the Neolithic period might have been facilitated the settlement of Wolaitta in Omo River Valley at least 10,000 to 8000 years ago (Brand et'al., 2012, 2017; Asmera; 2015; Fisher, 2017). The existence of some of the remains such as rock-shelters, palace centers, tombs, steal stones, urban centers, tools, material remain and others antiquities in Wolaitta indicates their settlement in Omo Valley. The production of $u t a$ appeared also in the area between $4^{\text {th }}$ to $3^{\text {rd }}$ millennium $\mathrm{BC}$, was one of the confirmation of the settlement of Wolaitta in Omo river valley (Cavanna, 2005).

The man-made caves and engravings in Wolaitta have also signifies the settlement of the people in the area. For this fact, Cavanna (2005, p.15) confirms "the territory of the Wolaitta region includes many geological strata of volcanic origin, therefore, it is at most impossible to find natural caves of carsick origins like in Europe." This witnesses that most Wolaitta caves were graved by settlers. The existence of engravings had various pictures such as animals and other social way of life. The caves had been used for shelter. Cave shelters were used as permanent place before the beginning of construction of Wolaitta-beehive shaped huts. This points the long settlement deeds of indigenous inhabitants of Wolaitta in Omo Valley. 
Besides, the making of cave by humans indicates indigenous knowledge how to keep themselves from various social and natural threats.

Majority of the caves were found eastern encampments of Omo River Valley at Kindo mountains such as Gaza, Didaye, Kindo, Wodena, Borkoshe, Koyisha and others which are elevated up to 3000 meters sea level which is suitable for $u t a$ (false-banana) plantation. The caves that indicate some remains found in Kindo mountains and near by places. These include Aruya, Zuliya, Arujjia, Wawu, Harurona, Sanna, Karetta Shucha (Black stone), Kindo Koysha, Akrissa and the like. Some caves such as Moche-Borago (on southwest side of Mount Damota), Galato cave; natural cave, Wogane in southeast of mount Damota (Brandt et'al., 2012, 2017), Amigoda (Zala-Shashsha) and other caves (Geramo, 2010) in Wolaitta indicate the settlement of the people in the area. The man made caves was one of the confirmations of settlement in Wolaitta.

In addition, informants claim engravings on caves might have been one of the communication means like the as sign and/ or script of ancient civilizations. However, nobody could read and interpret it despite the attempts of oral informants and recent archaeological findings. The other development is that of the symbol observed with different pictures which gives a vivid information about Wolaitta past. Even though these caves have ancient remains of Wolaitta, nobody has preserved it from both man-made and natural threats. These sites are endangered due to lack of heritage conservation strategy. The early inhabitants used these caves for the purpose of shelter at the beginning. Later on, they proceed to the construction of small huts and left to live in it. The construction of hut is developed the making of many architectural designed houses of Wolaitta such as Sina, Baqiya, Zufa, Burariya, Gulanta, Meshua and Dilam-Meshua. Wolaitta traditional hut modeled on the bases of caves which indicates the ingenious wisdom of the community.

The architectural design of the construction of houses were one of the indication that the people had ancient civilization and their permanent settlement hold up in Omo River Valley. After people began living in huts, the caves have become home for hyena, echidna, leopard, insects, rat, snakes and so on. Some of the engravings were also destroyed due to man-made factors and natural factors such as weathering and has been changing its original shapes. Most of the existing engraving symbol represents cattle, especially ox, caw and the like (Germao, 2010). Some symbols represent sun, moon, axes (kalta), panel, home use materials, stone tools, cups \& other lithic- artifacts/stone tools different stripe of lines.

Therefore, the engravings of caves appeared between 3000 BC and 2000 BC (Fisher, 2010) are one of the indication for the settlements of Wolaitta in Omo River Valley. The existence of engraving on caves and rocks is a witnesses that of the ancient settlements of the community. The symbol and representation found on rock and caves indicate the existence of relatively advanced art and wisdom. For instance, cattle on engravings was one of the indications of the domestication of animals for various purposes. The symbols of animals (cattle) also indicate that the economy of the area was based on cattle herding and farming (Fisher, 2010; Asmare, 2015). Through the process of change and continuity, they developed other socio-cultural achievements. It was for this reason that the archaeological investigation in the area is vital to feel the gap of oral tradition and written records.

The existence of such sources on remains of settlements would be vital instrument to prove Wolaitta people are indigenous in Omo River Valley which disproves the Proto-Hamitic hypothesis. For this reason, oral traditions associate that there were some earlier settlers in Wolaitta by their respective terms as Badiya, Badigadala, Gada, Arujia and the like. Besides, clans such as Wolaitta-malla, Zirgo-malla, Arigama, Walisa, Woshesha, Kominiya and few others were believed to be the inhabitants in Wolaitta (Awato, Banjawu and Ansebo, 1991; Wagesho, 1994; Gutulo, 2003; Geramo, 2010). On the other-side, the recent archaeological findings and oral tradition confirm that the horn of Africa (including Ethiopia) and Omo River Valley (Wolaitta) in particular is the homes of settlement (Cavanna, 2005; Bradt, et al., 2012, 2017; Dunnvant, 2017).

Even though sources reject the Proto-Hamitic hypothesis, there are few believers on it. They believed that some people of Ethiopia were migrated from Middle-East. Their hypothetical base were the story of Agazians Semetic groups (Tigrian descendants in Ethiopia and Eritrea) and the Old Testament story. According to northern Ethiopian oral tradition, Agazians were group of people migrated from Semetic origin in Euro-Asia. This tradition does not prove the settlement of Cushetic and Omotic South. The believers of proto-Hamitic hypothesis also links the story of Old Testament, book of Genesis, chapter nine verses 18-27, and Genesis Chapter ten verses 6-20. In this part of the Bile, it is stated that Noah cursed Ham, who was the father of Canaan, and the curse of Noa was said to be manifested on successors of Ham to became servants and slaves (The Bible Society of India, Holy Bible, Good News Edition, Today's English Vision, no date, p.12). Thus, the cursed descents came and settled in North-Eastern Africa from which they believed that the Cushetic including Wolaitta have descended from Hamatic.

One of the propagator of Proto-Hamatic notion was Charles Gabriel Seligman. He argues that the Hamites are crossed the Red Sea from Middle East and finally settled in the Horn of Africa. Some of the propagators who accepted Seligman hypothesis were Beckingham and Huntingford (1954), Ullendorff (1955, 1964), Hammerschmidt (1965, 1987), Sanders (1969), Stanley (1989), and Braukpmper (2004). They believed that immigrants who controlled Ethiopia and the Horn of Africa had come before the Semites and advocates white racial stock migration into Africa. They brought their civilizations to indigenous black African people, hence, they committed to link any indigenous African civilization to Hamites. This notion was reflected by a local and an amator writer, 
Wagesho. He believed this hypothesis and speculated that the earlier inhabitants of Wolaitta were came from Asia by crossing Bab-el-Mandeb and settled in the present location (Wagesho, 1994). Nevertheless, his argument was neither based any archaeological /written historical source nor supported by oral tradition.

Contrary to the proto-Hamatic hypothesis, the Anti-Hamatic notion states Africa in general and Ethiopia in particular was origin of humans. The Anti-Hamatic notion provides reliable scientific proves. The archaeological findings, oral tradition and other recent records of evidences proves that Wolaitta is the indigenous people to Omo Valley in particular (Gutulo, 2003; Amado; 2003; Lambebo, 2016; Chiatti, 1984; Fisher, 2010; Alaro, 1982; Brandt et'al, 2012, 2017) since Africa is home of human origin (Kebede, 2004). The Anti-Hamatic notion provided scientific evidences to explain that Africa is the cradle of human being. It also points out that people from Africa had moved to other continents at the end of glacial period. Besides, some of the advocators of this idea are also Delebo (1982), Greenberg (1963), Asfawu (1992), Bekerie (2004), Kebede (1993), White (1994, 2003), Clark (2003), Bender (1975, 1976), Fleming (1976, 2006) and other pro-Africanist professional who states Africa in general and Ethiopia in a particular is a home the achievements of civilization. This notion indicates Africa had its contribution to the settlement and other socio-cultural achievements of the world.

Moreover, the archaeological investigation in Awash and Omo Valley (where Wolaittta situated) confirms the sites as the home for human origin. The antithesis against proto-Hamitic hypothesis points the existence of family descents, and others remains of the past (Semaw, 2000; Solomon, Degsew, Blade, Fantahun, Seminew, Bisrat and Misganaw, 2016). This notion claims that certain places such as Awash and Omo valleys in Ethiopia are home for the settlement of human being. It is clear that the findings from the investigation in Omo Valley (Wolaitt found) and Awashs Valley support each other to indicate settlement. It is for this fact that Afar region and the excavation of Lucy in Awash valley as well as Omo River Valley were proved as the origin of human being in Ethiopia (Beke, 1850; Spöttel, 1998; Kebede, 2004; Fisher, 2010). This shows that Wolaitta is indigenous people in Ethiopia has been living at Omo River valley. Thus, the archaeological and other evidences proved that the settlement of Wolaitta was begun in Omo River Valley at least contemporary to other reverine settlement in elsewhere (Gutulo, 2003; Amado; 2003; Lambebo, 2016; Chiatti, 1984; Fisher, 2010; Alaro, 1982; Brandt et'al, 2012, 2017; Cavanna, 2005; Brandt, et'al,, 2012, Dunnavant, 2017; Asmare, 2015).

\section{CLANSHIP OF WOLAITTA}

The classification of Dolla-Woyisha Vs Tossa-Woyisha was based on priority of settlement in Omo Valley, where as Malla Vs Dogalla was based on socio-political and economic status in the community. Hence, the classification of clans to either Dolla-Woyisha Vs Tossa-Woyisha and/or Malla Vs Dogalla was not based on blood. However, sub-classifications of each broad categories of clans claim blood link of their descent. Hence, the clan category of Malla or Dogalla could be grouped into Dolla-Woyisha or
Tossa-Woyisha and vis-a-vis. Apart from this, the Malla were practitioners of aristocracy in which their descendants were believed to be rulers. The Dogalla were the practitioners of religious rituals. The majority of clans were categorized under Dogalla and Tossa-Woyisha based on their respective category. The clan status was varied from one another, and all of them believed that the early settlers of Wolaitta lived in Kindo of Omo River Valley (Wagesho, 1994; Balisky, 2009; Awato et' al., 1991; Chiatti, 1984). Among the sub-clans of Dolla-Woyisha such as Wolaitta-Malla, Zirgo-Malla, Arganma, Walisa, Woshesha and Kominiya were believed to be early inhabitants of Dolla-Woyisha clan. Other sources and oral tradition also mention Badiya, Badigadala, Halala, Hilala and Arujia as early inhabitants of Wolaitta.

Informants confirm some Dolla-Woyisha clan clusters were grown from soil Omo River valley. For this reason, the earlier inhabitants of Wolaitta clan were known as Dolla-Woyisha meaning a descent who were grown from the soil. The oral tradition believed that their ancestors were created and grew from soil in Omo River Valley. Hence, divisions of of Dolla-Woyisha clans are believed to be grown from soil and earlier inhabitants, whereas the divisions of Tossa-Woyisha clans were believed to be descended from other areas, and they were said to be implanted clans or immigrated to Omo Valley since ancient time. This was the evidence and accepted belief in the community that clans of Tossa-Woyisha were immigrated and assimilated with earlier inhabitants; Dolla-Woyisha. The term Tossa-Woyisha clan indicates the late immigrants from different parts outside Wolaitta. Thus, the fundamental bases for the classification to be said Dolla-Woyisha and Tossa-Woyisha was their claim of origin with in Wolaitta and outside it, and the ownership of settlement priority.

The divisions of clans under Dolla-Woyisha were created and originally lived there since the time immemorial. The oral tradition state that Dolla-Woyisha created as of earth creation to indicate that they lived in Omo Valley since long ago. Dolla-Woyisha clan claim their earliest and permanent place at Kindo, in east bank of the Omo River, and its surrounding caves such as Wawu and Arujia. Dolla-Woyisha clan was the earlier settlers of the Omo River Valley, the community call them as "Bitta-awa" meaning the father of the land. To claim their priority of settlement and origin to the area, the community araise the following question among each other in social occasions. The community crosscheck the membership of each individuals by asking clans as follows; Ne dolla Woyishe, tossa Woyishe? translates as; Are you a Wolaitta who grown up from ground or planted? The divisions of Dolla-Woyisha clans feel a sense of priority over the Tossa-Woyisha. Thus, the first born Wolaitta considered themselves as bitta awa (fathers of the land), and this notion believed that Wolaitta was lived in Omo River Valley of Kindo hill, who were sprung from the ground. This is to indicate that Dolla-Woyisha clan as the pioneers, earlier settlers and the owners of the land. The oral tradition points Badiya, Badigadala, Halala, Hilala and Arujia as the earliest dwellers at Kindo hill who were living for thousands of years. After early settlers begun farming, the settlement 
territory became Oyidu Kindo (Abbink, 2010; Balisky, 2009; Elias and et' al, 1991; Gutulo, 2003; Chiatti, 1984). These Oyidu Kindo was the settlement areas in Wolaitta history and gradually whole Kindo hills and vast territory beyond Oyidu-Kindo was occupied by Wolaitta clans. Besides, Wolaita-Malla and other seven clans also began to settle in an organized life too. Contrary to Dolla-Woyisha, Wolaitta oral tradition states other category of clans in Wolaitta as Tossa-Woyisha to indicate the members of these clans were immigrated from other areas and assimilate to existing Wolaitta in long process of time.

The settlement priority and claim of origin to either Omo River Valley or outside it as Dolla-Woyisha or Tossa-Woyisha was the indication of inhabitants in the area. Those clans divisions who claimed the origin to the Omo River Valley were Dolla-Woyisha, and those clans divisions who claimed their origin to out of Omo River Valley were Tossa-Woyisha. Even though clans of Wolaitta trace heterogeneous origins of various places of Ethiopia, nobody knows when each of the clans immigrated and were assimilated to existing divisions of Tossa-Woyisha clans except Tigre clan. The exact number of subdivision of clans are not known. The numbers of clans are varied among sources. Some list them up to one hundred and others extends or reduces them to less than one hundred. For instance, Chiatti (1984) listed one hundred eighteen sub-clans each claiming its origin from different places and social functions, and Dea (2000) claims more than one-hundred clans.

Besides, Balisky (2009) states eighty-eight clans, and Wagesho (1994), an amateur writer listed one hundred one clans. Abraham Babanto (1979) also an amateur and indigenous writer listed one hundred ten clans. Thus, Wolaitta was patriarchal society in which eldest son was heir for family and clan matters. Cimma (elders) had responsibility to pass the whole socio-cultural matters to the generation. They also taught the younger generation about the Mayza-woga (ancestral culture). The marriage relation among the sub-division of Wolaitta clans had exogamous marriage relation and never marry from his/her father and mother lineage. The respective clans had also specific burial place in their ancestral land and other sociocultural shares in common.

Apart from archaeological and other scientific proofs, the anti-Hamitic notion emanates from oral tradition. It states that the Omotic family such as Wolaitta, Konta, Gofa, Kucha, Dawuro, Gamo, Boroda and others had one ancestor, and believed that their original birth place was Omo River. They were considered as brothers who were settled to the present territory and they had the same socio-cultural and political similarity since the time immemorial. This shows Wolaitta and and it neighboring people had common descent in its origin. They lived a long period around various caves such as Waho, Arujia, Moche-Borago and others. They had common history of state formation and administrative center claim in Omo River Valley. Mala clans had become aristocratic since ancient time. For instance, Wolaitta-mala which is old among all dynasties of the area usurped authority on rest clans and had became popular in the area. Wolaitta-mala had begun to rule the rest clans in Omo River Valley until the above people were separated as independent state since $13^{\text {th }}$ century. The dominancy of Wolaitta-mala

clan was weakened in $13^{\text {th }}$ century. For this reason, the rest groups established their separate chiefdom and kingdoms, more specifically since sixteenth century (Dea, 200; Gutulo, 2003; Balisky, 2009).

Furthermore, informants assert that etymologically even the word Wolaitta is derived from their ancestral forefather "Wolaitta." Informants also designate "Wolaitta" as male ancestor and call him as their forefather. They also believed him as once a warrior and his descent developed in to clan and had taken leadership position. The clan of Wolaitta became ruler and took the title mala which means ruler. Wolaitta clan added the suffix mala which became Wolaitta-Malla clan. Thus, Wolaitta-Malla clan was the dynasty in Wolaitta, and the rest mala clans were probably once ruled the area. It is said the joint of Omo and Deme river was the first areas where the Wolaitta kingdom laid a base for its foundation and future expansion. Within a gradual process, the Kingdom of Wolaitta was able to conquer Omotic areas. For this reason, the anti-Hamitic tradition which is explained by oral informants is similar with the existing literature and the recent archaeological findings. All sources confirm that Kindo was the original home land for Wolaitta.

Hence, concerning the overall claim of Wolaitta earlier settlement at Omo River Valley, almost all sources support each other. There is no overlapping notion on scholarly works and oral tradition regarding the origin of the Wolaitta earlier settlement, and all confirm that the origin was Omo River Valley. For instance, some scholars ( Balisky 2009; Alaro 1982; Chatti 1984; Awato, Bajawu and Ansebo, 1991; Gutulo, 2003) indicated the existence of Wolaitta since ancient time in Omo Valley especially in Kindo. Moreover, a noted Ethiopian historian, Zewde (2002, p.31) concluded that "the Omotic-speaking peoples derive their name from their location on both sides of the Omo River. Situated exclusively in south-western Ethiopia, they (Omotic peoples)...the evolution of highly organized polities." Thus, as Omo River Valley community Wolaitta has various socio-cultural achievements after their settlement and claship.

In the same manner, Delébo (1982) remarks the existences of different Wolaitta-Gamo peoples in the Omo valley from ancient time to 1270 A.D, and Tamirat (1972) too claimed the significance of Omo River Valley to settlements. Thus, the largest portion of literature on the Wolaita, portray the idea that their ancestor had lived in Kindo, vicinity of the Omo River Valley which is substantiated by archaeological evidences from some caves especially, Moche-Borago cave in Mount Damota (Cavanna, 2005; Dunnavant, 2017). Informants also states the earlier inhabitants of Wolaitta; Dolla-Woyisha lived in Kindo. It was said that the social organization and state formation of Wolaitta had begun after the settlements in Omo River Valley and its subsequent socio-cultural developments. Evidences indicate that the achievements of Wolaitta was contemporary to Axumite kingdom. Therefore, the settlement and clanship as well as state formation appeared in Wolaitta since ancient time. 


\section{Settlement and clanship of Wolaitta in Omo River Valley of Ethiopia}

\section{CONCLUSIONS}

The settlement of Wolaitta was begun in Omo River Valley. The domestication of crops such as uta (false banana) and wolaitta-donuwa (wolaitta-potato), and animals such as mizaa (cattle) in Omo River Valley during the Neolithic period was one of the confirmation of settlement of Wolaitta to the area. The existence of man-made caves and engravings on it also points Wolaitta people lived in this area since the time immemorial. The settlement also facilitated the state formation and other sociocultural way of life. The oral and other evidences states that some sub-clans of Dolla-Woyisha such as Wolaitta-malla, Zirgo-malla, Arigama, Walisa, Woshesha, Kominiya and the like were believed to be first born clans. Besides, there were settlers such as Badiya, Badigadala, Halala, Hilala and Arujia who were believed as ancient inhabitants of Wolaitta. The dsub-clans of Tossa-Woyisha were immigrated and assimilated with clans of Dolla-Woyisha which in turn led Wolaitta to be organized society in Omo River Valley.

\section{REFERENCES}

1. Abbink, JG. (2010). Encyclopedia Aethiopica, Vol. 4, O-X. In Siegbert Uhlig (Editor), Harrassowitz Verlag, Wiesbaden.

2. Alaro, A. (1982). The Political History of Wolaitta in the eighteenth and Nineteenth centuries. BA hesis, Addis Ababa Univeristy.

3. Allen, RC. (1997) Agriculture and the Origins of the State in Ancient Egypt. Explorations in Economic History, 34(3): 135-154.

4. Amha, A. (2010). Encyclopedia Aethiopica, Vol. 4, O-X. In Siegbert Uhlig (Editor), Harrassowitz Verlag, Wiesbaden.

5. Asfaw, B., Beyene, Y., Suwa, G., Walter, R. C., White, T. D., Wolde Gabriel, G., \& Yemane, T. (1992). The earliest acheulean from konso-gardula. Nature, 360(6406), 732.

6. Asmare, MT. (2015). Reconstructing Food Systems from the Late Holocene Context of Mochena-Borago Rock shelter, Wolayta, Southern Ethiopia. MA Thesis, Addis Ababa University, Ethiopia.

7. Awato, E., Banjawu S. \& Ansebo,A. (1991). Ya Semen Omo Hizboch Poletikawi Tarik (A Political History of North Omo People). Kifil andi, Ya Semen Omo bahil Mastaweqianna Turizim Memiria, Arbaminch.

8. Babanto, A .(1979). Lämlämetua Wolayta: Tentawenna Yä Zaräyetu ("The Origin of Wolaita and Revolutionary Modern Wolaita").

9. Balisky, PE .(2009). Wolaitta Evangelists: A Study of Religious Innovation in Southern Ethiopia, 1937-1975. American Society of Missiology Monograph Series, 6, Pickwick Publications, Wipf and Stock Publishers, Eugene, USA.

10. Beckingham. C.F. \& Huntingford, G.W.B. (1954). Some Records of Ethiopia (1593-1646). N.P: London.

11. Beke, C.T. (1850). On the Geographical Distribution of the Languages of Abessinia and the Neighbouring Countries. Journal of the Ethnologica Society of London (1848-1856), 2: 208-223

12. Bekerie, A. (2004). Ethiopica: Some Historical Reflections on the Origin of the Word. International Journal of Ethiopian Studies, 1(2): 110-12

13. Bender, M. L. (1976). Language in Ethiopia. London: Oxford University Press.

14. Bender, M. L.(1975) Omotic: A New Afroasiatic Language Family. Museum Series, Southern Illinois University: Carbondale.

15. Bulliet, R. (2011). The Earth and Its Peoples: A Global History, 5th Edition, Volume 1: To 1550. Wadsworth: Boston, USA.

16. Brauk£mper, U.(2014). A history of the Hadiyya in Southern Ethiopia. Translated from German by Geraldine Krause, Wiesbaden: Harrassowitz Verlag.

17. Brandt, S. A., Fisher, E. C., Hildebrand, E. A., Vogelsang, R., Ambrose, S. H., Lesur, J., \& Wang, H. (2012). Early MIS 3 occupation of Mochena Borago Rockshelter, Southwest Ethiopian Highlands: implications for LatePleistocene archaeology, paleoenvironments and modern human dispersals. Quaternary International, 274, 38-54.

18. Brandt, S. A., Fisher, E. C., Hildebrand, E. A., Vogelsang, R., Ambrose, S H., Lesur, J., \& Wang, H. (2017). A new MIS 3 radiocarbon chronology for Mochena Borago Rockshelter, SW Ethiopia: Implications for the interpretation of Late Pleistocene chronostratigraphy and human behavior. Journal of Archaeological Science: Reports, 11: 352-369
19. Brown, K. and Ogilivie, S. (2009). Concise Encyclopedia of Languages of the World. Oxford

20. Cavanna, C. (2005). Wolayta:Una Regione D’Etiopia, Studi e Ricerche (1995 - 2004) ("Wolayta: An Ethiopia Region Studies and Research(1995-2004)'. Societa' Naturalistica Speleologica Maremmana, Grosseto.

21. Central Statistical Authority (2008). Ethiopian Statistical Abstract: Federal Democratic Republic of Ethiopia, Population and Housing Census. Brahanena and Selam Printing Press, Addis Ababa

22. Cerulli, E. (1956). Peoples of Southwest Ethiopia and its Border Land. International African Institute, London.

23. Chiatti, R. (1984). The Politics of Divine Kingship in Wolaita (Ethiopia), 19th and 20th Centuries. PhD Thesis, University of Pennsylvania.

24. Clark, J.D. (1962). The Spread of Food Production in Sub-Saharan Africa. The Journal of African History, 3(2): 211-228.

25. Clark, J.D. (1994). African Homo erectus: old radiometric ages and young Oldowan assemblages in the Middle Awash Valley, Ethiopia. Science, 264(5167): 1907-1910

26. De'a, D. (2000). Cultural Variation and Social Change in Southern Ethiopia: Comparative Approaches: Clans, Kingdoms, and 'Cultura Diversity' in Southern Ethiopia: The Case of Omotic Speakers Northeast African Studies, 7(3): 167-169.

27. Delebo, L.G. (1982). Ye Ethiopia Regim Ye Hezb ena YeMebgist Tarik (A long History of Ethiopian People and Government). Nigid Matemiya Bet (Commercial Printing Press), Addis Ababa.

28. Doda, Z. (2006). An Ethnographic Overview of Enset Producing Peoples of Ethiopia. Presented at the Review Workshop, Debub University, Awassa.

29. Ehret, C. (1979). On the Antiquity of Agriculture in Ethiopia. The Journal of African History, Cambridge University Press, 20 (2):161-177.

30. Feary, S., Brown, S., Marshall, D., Lilley, I., McKinnon, R., Verschuuren, B., \& Wild, R. (2015). Earth's cultural heritage. Protected Area Governance and Management; Worboys, GL, Lockwood, M., Kothari, A., Feary, S., Pulsford, I., Eds, 81-116.

31. Farelius, B. (1993). Where does the Hamite belong?. Nomadic Peoples, 32:107-118.

32. Fisher, E. C. (2010). Late Pleistocene Technological Change and Hunter-gatherer Behavior at

33. Moche Borago Rockshelter, Sodo-Wolayta, Ethiopia: Flaked Stone Artifacts from the

34. Early OIS 3 (60-43 Ka) Deposits (Doctoral dissertation, University of Florida).

35. Fleming, H. C. (1976). Omotic overview. The non-Semitic languages of Ethiopia, 299-323.

36. Fleming, H. C. Ongota: a decisive language in African prehistory (Vol. 64). Otto Harrassowitz Verlag.

37. Geramo, Z.C. (2010). Yetedafenawu yewolayita tarik findata ina leloch merejawoch (A hidden history of Wolaitta and related information).

38. Greenberg, J.H. (1963). The Languages of Africa. Bloomingiton: Indiana University Press.

39. Gutulo, A.G. (2004). Kedemit Wolayttana Kafa (Early Wolaitta and Kaffa). Artistic P.E.

40. Haberland, E. (1975). Notes on the History of the Southern Ethiopian Peoples. Center National de le Rechereche, Colloque International Sur Les Langues Couchitiques Et Les Peuples Quri Les Parlent.

41. Hammerschmidt, E. (1965). Jewish Elements in the Cult of the Ethiopian Church. Institute of Ethiopian Studies, 3(2):1-12.

42. Hammerschmidt, E. (1987). Studies in the Ethiopic Anaphoras (Athiopistische Forschungen). 2nd Edition, Wiesbaden, 1987.

43. Hidoto, Yacob. (2015). "Cattle Counting Ceremony among the Wolaita (Ethiopia): Exploring Socio-Economic and Environmental Roles." Open Journal of Ecology 5, 5(1): 159-173.

44. Institute of Biodiversity Conservation. (2012). Ethiopia: Third Country Report on the State of Plant Genetic Resources for Food and Agriculture. Addis Ababa

45. Jufare, A.T. (2008) Livelihood Adaptation, Risks and Vulnerability in Rural Wolaita, Ethiopia. PhD Thesis, Norwegian University of Life Sciences, UMB.

46. Kebede, M. (2004). Africa's Quest for a Philosophy of Decolonization. Philosophy Faculty Publications: University of Dayton.

47. Lambebo, A.S. (2016). A Study of Reconstructing the Historical Link between Wolaitta and Damot Kingdom of Wolaitta in Ethiopia International Journal of English Language Literature and Humanities, 4(4): 268-284. 
48. Levine, DN. (1974) Greater Ethiopia: The Evolution of A Multiethnic Society. The University of Chicago Press.

49. Mokhtar, G. (Ed.). (1981). Ancient civilizations of Africa. Unesco.

50. Olango, T. M., Tesfaye, B., Catellani, M., \& Pè, M. E. (2014). Indigenous knowledge, use and on-farm management of enset (Ensete ventricosum (Welw.) Cheesman) diversity in Wolaita, Southern Ethiopia. Journal of ethnobiology and ethnomedicine, 10(1), 41.

51. Sanders, E. R. (1969). The Hamitic hyopthesis; its origin and functions in time perspecive. The Journal of African History, 10(4), 521-532.

52. Scanes, C. G. (2018). The Neolithic Revolution, Animal Domestication, and Early Forms of Animal Agriculture. In Animals and Human Society (pp. 103-131). Academic Press.

53. Seligman, C.G. (1966). Race of Africa. 4th Edition, Oxford, London.

54. Semaw, S. (2000). The World's Oldest Stone Artefacts from Gona, Ethiopia: Their Implications for Understanding Stone Technology and Patterns of Human Evolution Betwee $2 \cdot 6-1 \cdot 5$ Million Years Ago. Journal of Archaeological Science, 27: 1197-121.

55. Shillington, K. (2005). History of Africa (Revised 2nd Edition). Palgrave Macmillan.

56. Solomon, Tadele, Degsew Zerihun, Blade Engda, Fantahun Zelelew, Seminew Asrat, Bisrat G/Egziabher, Misganaw G/Michael (2016). A Catalog on Ethiopian Archeological andPaleontological Sites Vol.I-Afar. Authority for Research and Conservation of Cultural Heritage.

57. Spencer, C.S. (2010). Territorial expansion and primary state formation. Proccedings of the National Acedemy of Sciences, 107 (16): 7119-7126.

58. Spöttel, M.(1998). German ethnology and Antisemitism: the Hamitic Hypothesis. Dialectical Anthropology, 23 (2): 131-150

59. Stanley, H.M. (1899). Through the Dark Continent or the source of the Nile Around the Great Lakes of Equatorial Africa and Down the Living Stone River to the Atlantic Ocean, Vol. I. George Newnes Limited Mineola: London.

60. Tamirat, T. (1972). Church and State in Ethiopia, 1270-1527. Oxford, Clarendon Press.

61. The Bible Society of India. (No date). Holy Bible, Good News Bible:Today's English Vesion. Bangalore, India.

62. Turchin, P., Whitehouse, H., Korotayev, A., Francois, P., Hoyer, D., Peregrine, P., ... \& Currie, T. E. (2018). Evolutionary Pathways to Statehood: Old Theories and New Data

63. Ullendorff, E. (1955). The Semitic Languages of Ethiopia and their contribution to general semitic studies. Africa 252 (1955): 154-1960.

64. Ullendorff, E. (1960). The Ethiopians: An Introduction to Country and People. Oxford: Oxford University Press

65. University of Plymouth. (2017). Could the Neolithic Revolution offer evidence of best ways to adapt to climate change?. ScienceDaily, <www.sciencedaily.com/releases.htm>.

66. Wagesho. W. (1994). Ya Wolayta Hezib Tarik (The History of Wolaita). 2nd Edition, Brahannena Salam Printing Press, Addis Ababa.

67. Wescott R.W. (1970).The Enumeration of Civilizations. History and Theory, 9(1): 59-85.

68. White, Tim D., Gen Suwa, and Berhane Asfaw. (1994). Australopithecus ramidus, a new species of early hominid from Aramis, Ethiopia." Nature 371, no. 6495: 306

69. White, Tim D., Gen Suwa, and Berhane Asfaw.(2003). Pleistocene homo sapiens from middle awash, ethiopia. Nature,423(6941), 742-747.

70. Wolaitta Zone. (2017). Preliminary Survey on Wolaitta Population. Report. 